\title{
A Threshold-Based Decision-Support System for Fungicide Applications Provides Cost-Effective Control of Citrus Postbloom Fruit Drop
}

\author{
Andre B. Gama, ${ }^{1 \dagger}$ Geraldo José Silva Junior, ${ }^{2}$ Natalia A. Peres, ${ }^{3}$ Juan Edwards Molina, ${ }^{1}$ Lilian M. de Lima, ${ }^{4}$ and Lilian Amorim ${ }^{1}$ \\ ${ }^{1}$ Plant Pathology, Universidade de Sao Paulo Escola Superior de Agricultura Luiz de Queiroz, Piracicaba, SP, Brazil \\ ${ }^{2}$ Research and Development, Fundo de Defesa da Citricultura, Araraquara, SP, Brazil \\ ${ }^{3}$ Gulf Coast Research and Education Center, University of Florida, Wimauma, FL, U.S.A. \\ ${ }^{4}$ Economy, Universidade de Sao Paulo Escola Superior de Agricultura Luiz de Queiroz, Piracicaba, SP, Brazil
}

\begin{abstract}
Postbloom fruit drop (PFD) of citrus, caused by Colletotrichum acutatum sensu lato and C. gloeosporioides sensu lato, is an important disease in the humid tropics of the American continent. PFD mainly affects flowers, on which typical symptoms are characterized by orange-brown lesions with presence of acervuli. The disease has a sporadic occurrence, but preventative fungicide sprays are applied every season. The objective of this study was to evaluate the effectiveness of a fungicide spray strategy for PFD based on a predictive model of $C$. acutatum conidium germination linked to weather conditions. Fungicide sprays were performed when the model predicted pre-established thresholds of $10,15,20$, and $25 \%$ of germinated spores (T10, T15, T20, and T25, respectively). Five experiments were conducted in two different seasons in the state of São Paulo, Brazil. PFD control efficacy of the threshold-based treatments was compared

with a nontreated control and to a calendar-based spray system. Additionally, an economic analysis was performed to assess the gross income revenues of the fungicide spraying strategies. Disease control in plots treated at T10, T15, and T20 was as effective as the calendar-based strategy. The number of fungicide applications was reduced by 33 to $71 \%$ when sprays were applied at T15 and T20, and gross income increased or was comparable to that of the other treatments. Therefore, using a conidium germination model with a threshold of 15 or $20 \%$ is recommended as a spraying strategy for PFD management in Brazil.

Keywords: chemical control, Colletotrichum sp., decision support system, epidemiology, disease warning systems, disease forecast, Citrus sinensis
\end{abstract}

Postbloom fruit drop (PFD) or blossom blight is an important disease of citrus in the Americas (Silva-Junior et al. 2014a; Timmer et al. 1994). PFD is caused by Colletotrichum acutatum sensu lato (Brown et al. 1996; Timmer and Zitko 1996) and C. gloeosporioides sensu lato (Lima et al. 2011; McGovern et al. 2012). The C. acutatum complex includes several species (Damm et al. 2012). The disease was first reported in Belize (Fagan 1979), and PFD outbreaks have been observed in citrus-growing areas in the humid tropics and subtropics of the Americas, such as Brazil and the United States (Silva-Junior et al. 2014a; Timmer and Brown 2000; Timmer et al. 1994). Yield losses caused by PFD may reach $80 \%$ when several rainy days occur during the flowering period (de Goes et al. 2008; Silva-Junior et al. 2014b).

The pathogen survives in the absence of bloom as appressoria on citrus leaves (Zulfiqar et al. 1996) and weeds (Frare et al. 2016). During bloom, floral extracts and sugar compounds are washed off from citrus flowers onto leaves. The extracts induce appressorial germination and the production of secondary conidia (Agostini and Timmer

Current address of A. B. Gama: Gulf Coast Research and Education Center, University of Florida, Wimauma, FL, U.S.A.

Current address of J. E. Molina: Instituto Nacional de Tecnología Agropecuaria, Balcarce, Argentina

${ }^{\dagger}$ Corresponding author: A. B. Gama; andre.gama@ufl.edu

Funding: The authors are grateful to the São Paulo Research Foundation (Fundação de Amparo à Pesquisa do Estado de São Paulo [FAPESP]) for supporting part of this study (project no. 2014/19933-0); to FAPESP and to the National Council for Scientific and Technological Development (CNPq) for a Master's degree fellowship (project no. 2015/06007-2) to A. B. Gama; and to CNPq for fellowships to G. J. Silva Junior and L. Amorim.

The author(s) declare no conflict of interest.

Accepted for publication 14 April 2019.

(c) 2019 The American Phytopathological Society
1994; MacKenzie et al. 2010). These conidia are water-dispersed from leaves to healthy flowers (Agostini et al. 1993; Zulfiqar et al. 1996). Orange-brown lesions with acervuli are formed on petals (Fagan 1979; Timmer et al. 1994), and dark-brown necrotic lesions are formed on the stigma and style (Lin et al. 2001; Marques et al. 2013). The abundant conidia produced on petals are water-splashed onto other flowers on the citrus canopy (Peres et al. 2005). Optimal temperatures for conidial germination are between 22 and $27^{\circ} \mathrm{C}$, although conidium can germinate under temperatures ranging from 6 to $41^{\circ} \mathrm{C}$ (Agostini et al. 1992; Fagan 1979; Lima et al. 2011). Low temperatures delay PFD development, whereas high temperatures occurring during dry conditions shorten the blooming period of the citrus trees, which also hamper disease development. Infection of petal tissues occurs under wetness periods of 12 to $18 \mathrm{~h}$ at 19 to $30^{\circ} \mathrm{C}$ (Fagan 1979). Flower infections lead to hormonal changes and abscission of fruitlets (Lahey et al. 2004; Li et al. 2003). PFD is also characterized by retention of calyces on branches for several months, until the twigs or branches die (Peres et al. 2004; Timmer et al. 1994)

PFD is controlled by protective fungicide sprays in most of the citrus-growing areas in the Americas (de Goes et al. 2008; Peres et al. 2004; Silva-Junior et al. 2014b). In Brazil, demethylation inhibitor (DMI) and quinone-outside inhibitor (QoI) fungicides applied in prepackaged mixtures are the most effective options for PFD control (Silva-Junior et al. 2014b). In the United States, QoI fungicides as a single active ingredient or in tank mixtures with ferbam, DMI, and succinate dehydrogenase inhibitor fungicides are registered to control this disease (Peres and Dewdney 2018). Regardless of the weather conditions, growers usually spray fungicides every 7 to 14 days according to a calendarbased program (Peres et al. 2004; Silva-Junior et al. 2014b; Timmer et al. 1994). However, a calendar-based disease management strategy results in high production costs, sometimes with unnecessary sprays, because PFD outbreaks occur only when weather conditions are conducive for disease development (Silva-Junior et al. 2014a). In addition, the excessive use of fungicides or the incorrect timing of the application may accelerate the selection of fungicideresistant isolates (Brent and Hollomon 2007) or cause a control failure (de Goes et al. 2008; Peres et al. 2004), respectively. C. acutatum 
resistance to QoI-fungicides has already been reported in strawberry fields in Florida, USA (Forcelini et al. 2016). Thus, the establishment of C. acutatum-resistant populations may occur in citrus as well.

Alternative management approaches, such as decision support systems (DSSs) may be used as a more sustainable strategy to avoid excessive use of fungicides and, consequently, alleviate the selection pressure for fungicide resistance. These systems aim to predict increases in disease intensity and help decision makers solve problems under uncertain conditions (Madden and Ellis 1988; Shtienberg 2013). DSSs have been effective in managing diseases with fewer fungicide applications than calendar-based sprays without a significant loss of yield or quality in citrus and other crops (Cordova et al. 2017; Peres et al. 2004; Pertot et al. 2017). In the 1990s, the PFD model was developed and evaluated in Florida to guide citrus growers to spray fungicide only under PFD-conducive weather conditions (Timmer and Zitko 1996). However, the PFD model indicated sprays during nonconducive conditions (Peres et al. 2004). A newer DSS, the Postbloom Fruit Drop Fungicide Application Decision (PFD-FAD) was developed (Peres et al. 2002a) in the 2000s and tested in citrus orchards in São Paulo State, Brazil (Peres et al. 2004). The PFD-FAD calculates disease risk based on different variables, such as the intensity of flowers on the trees, PFD occurrence in previous seasons, rainfall events and wetness duration in previous days, and the last fungicide spray date (Peres et al. 2002a). The PFD-FAD has shown satisfactory results in the field and recommended fewer false-positive triggers than the PFD model (Peres et al. 2004). However, citrus growers from Florida and São Paulo have not been using this system extensively. A possible cause for the low adoption of PFD-FAD could be that it requires several inputs to be frequently assessed in the field to predict disease risk.

The Strawberry Advisory System (StAS) is an efficient DSS that has been widely adopted by strawberry growers in the southeastern United States, targeting Botrytis and anthracnose fruit rots, caused by Botrytis cinerea and C. acutatum, respectively (Cordova et al. 2017). This system works with automated weather station networks in the United States, and no assessments or inputs are required to be added by the growers. StAS is built on a user-friendly platform that provides warnings via e-mail or text messages (Cordova et al. 2017; Pavan et al. 2011). The threshold for fungicide applications on StAS is predicted by a model that calculates $C$. acutatum infection based on wetness duration and temperature.

An effective and less laborious PFD-DSS on a more userfriendly platform, such as StAS, is desirable to assist citrus growers on PFD control. Correlations between environmental variables and PFD progress, as well as spray threshold assessments, are required for the development of a PFD-DSS. Lima et al. (2011) developed a model in vitro for C. acutatum conidial germination under a range of wetness and temperature conditions. The model described that wetness periods of $12,24,48$, and $72 \mathrm{~h}$ under optimum temperatures around $25^{\circ} \mathrm{C}$ resulted in approximately $18,33,54$, and $68 \%$ of conidial germination, respectively. Further study correlated the conidial germination model by Lima et al. (2011) with sweet orange flower infection (Gonçalves and Amorim 2013). Thus, this study aims to evaluate different thresholds based on conidial germination to select the most suitable index to spray fungicide for PFD control. The efficacy and cost-benefit of the established thresholds were compared with the calendar-based sprays commonly used by growers for PFD control in sweet orange orchards in São Paulo State, Brazil.

\section{Materials and Methods}

Experimental areas. The field trials were undertaken in 2015-2016 (season 1) and 2016-2017 (season 2) in 10- to 20year-old orchards of Pera and Natal sweet oranges (Citrus sinensis) (Fig. 1). These two cultivars are rated as highly PFD-susceptible and represent almost $45 \%$ of the São Paulo citrus belt (Fundecitrus 2018). Experimental areas were located in the municipalities of Santa Cruz do Rio Pardo (area 1, 22 $48^{\prime} 42^{\prime \prime}$ S, 49 $21^{\prime} 42^{\prime \prime}$ W), Taquarituba (area 2, $23^{\circ} 37^{\prime} 01^{\prime \prime} \mathrm{S}, 49^{\circ} 13^{\prime} 35^{\prime \prime} \mathrm{W}$ ), and Iaras (area 3, 22 $2^{\circ} 2^{\prime} 43^{\prime \prime} \mathrm{S}$, $\left.49^{\circ} 01^{\prime} 26^{\prime \prime} \mathrm{W}\right)$, in southwest São Paulo state, Brazil, where PFD frequently occurs. Three iMetos IMT200 weather stations (Pess Instruments, Weiz, Austria), located less than $5 \mathrm{~km}$ from each experimental area, recorded air temperature $\left({ }^{\circ} \mathrm{C}\right)$, relative humidity $(\%)$, and rainfall (mm) hourly.

Experimental design and treatments. Treatments were arranged in a randomized complete block design with four replicates of 30 trees per block, divided in three-row plots (120 trees per treatment). A guard row between treated blocks was left unsprayed (Peres et al. 2004; Silva-Junior et al. 2014b). Treatments evaluated in this study were established to determine the most suitable threshold to indicate the need for fungicide sprays for PFD control. Fungicide applications were performed based on a predictive model for C. acutatum conidial germination considering wetness and temperature (equation 1) proposed by Lima et al. (2011). The model was subsequently adapted and validated in greenhouse experiments by Gonçalves and Amorim (2013). In season 1, the fungicide was sprayed when the model predicted $20 \%$ (T20) or 25\% (T25) conidial germination. In season 2, thresholds of $10 \%$ (T10), 15\% (T15), and 20\% (T20) conidial germination were tested. Threshold-based sprays were compared with a calendar-based system (CBS) and a nontreated control (NTC) for both areas and seasons. The predictive model was as follows:

$$
\begin{aligned}
y(t)=100 & \times\left[\left(\frac{t-6.31}{18.99}\right)^{1.12} \times 1.234\right] \\
\times & {\left[\left(\frac{40.69-t}{21.36}\right)\right] \times\left[1-1.02 \times 2.71810^{(-0.02 \times \mathrm{WP})}\right] }
\end{aligned}
$$

where $y(t)$ is the conidial germination index $(\%), t$ is the average temperature $\left({ }^{\circ} \mathrm{C}\right)$ during wetness period, and WP is the duration of the wetness period $(\mathrm{h})$.

Germination indexes were calculated hourly based on data obtained from the weather stations located in each area. Duration of the wetness period was estimated by the dew-point depression method, which is based on the difference between air and dew-point temperatures (Gillespie et al. 1993; Huber and Gillespie 1992). This model was chosen because it provides good estimates of wetness period and does not require several weather variables and sensors (Montone et al. 2016). The germination index is cumulative, depending on the duration of wetness period. A 4-h period of dryness interrupts wetness period, and germination index drops to zero (Fitzell and Peak 1984). Subsequently, in the first hour of the next wetness period, the model will start a new prediction of the germination index.

Fungicide sprays. Trees of the CBS treatment were sprayed from the R1/R2 stages (green buds) to the R7 stage (stigma and style fall and ovary growth) at 6- to 11-day intervals (Silva-Junior et al. 2014a, adapted from Agustí et al. 2000). In threshold-based treatments, trees were sprayed only when conidial germination reached the pre-established percentages, with a minimum interval between sprays of 7 days. Applications were performed with tower sprayers (Arbus 4000, Jacto, Pompeia, São Paulo, Brazil; or Alfa 4000, Natali, Limeira, São Paulo, Brazil) using 30 to $50 \mathrm{ml}$ of fungicide spray mixture per cubic meter of tree canopy. The spray volumes and fungicide rates were based on the tree-row-volume method (Silva-Junior et al. 2014b). The fungicide mixture of QoI + DMI (Nativo, 10\% trifloxystrobin + 20\% tebuconazole, Bayer CropScience) was sprayed at $2.8+5.6 \mathrm{mg}$ of active ingredient per cubic meter of the tree canopy (Silva-Junior et al. 2014b).

Disease symptoms and yield loss assessments. Sampling both sides of the trees, a total of 200 flowers (R5 stage, open flowers) were arbitrarily assessed from the two innermost trees of each plot and the incidence of PFD-symptomatic flowers calculated. The number of persistent calyces and the number of fruit set were assessed 3 months after flowering on 20 marked branches (10 branches per tree in the two innermost trees of each plot).

Statistical analysis. Univariate generalized linear models (GLMs) were used to analyze three PFD-related variables: symptomatic flower incidence, number of persistent calyces per branch, and number of fruit per branch. Each combination of area and season was individually analyzed. Binomial or quasi-binomial distributions were 
tested, owing to the possible overdispersion of data, for modeling symptomatic flowers. Count data as persistent calyces or fruit set were analyzed using Poisson, quasi-Poisson, or negative binomial family distributions. The Akaike information criterion (AIC) was compared among models with different family distributions, selecting the model with the lowest AIC value. Fixed-effect models were fitted for the individual analysis with fungicide spray treatments and blocks as fixed factors using the GLM function of the "stats" R package (R Core Team 2018). The function "lsmeans" from the lsmeans $\mathrm{R}$ package (Lenth 2016) was used to estimate the least-square means of treatments and to conduct post-hoc comparisons among them by Tukey test at a significance level of 5\%. This analysis methodology was based on Madden et al. (2000) and Hughes and Madden (1995).

Economic analysis. Two different analyses for spray costs and price indexes were considered to determine the economic viability of the DSS. Spray costs were estimated seasonally for each treatment based on fungicide, labor, and machinery prices in São Paulo state. Spray costs for 2015-2016 (season 1) were deflated to provide an accurate basis for comparison with 2016-2017 (season 2) costs using the 2016 Brazilian Inflation Index "IGP-DI" (Institute for Applied Economic Research [IPEA] database, http://www.ipea.gov.br). Deflation was based on the real cost equation proposed by Hoffmann (2006). Deflated spray costs from 2015-2016 in Brazilian currency $(\mathrm{R} \$)$ were converted into U.S. dollars (US\$) using the average exchange rate of 3.338 (IPEA database). Spray costs in R \$ from 2016-2017 were converted into US\$ at an exchange rate of 3.4817 (IPEA database). Estimated gross incomes (US\$ per hectare) considering spray costs of each treatment were compared using Tukey's test $(\alpha=0.05)$. Data were analyzed using Statistica 13.3 (StatSoft, Tulsa, OK).

Yield values were predicted from the fruit set data based on the model obtained by Silva-Junior et al. (2014b) for yield and fruit set. Gross income was calculated multiplying the predicted yield in units of boxes per tree by the number of trees per hectare by the sweet orange fruit box price. The annual average prices of a $40.8 \mathrm{-kg}$ fruit box were US\$5.37 and US\$6.09, for 2016 (season 1) and 2017 (season 2), respectively (Center for Advanced Studies on Applied Economics [CEPEA] database, https://www.cepea.esalq.usp.br/en).

A price index analysis was also performed to compare treatments. Spray costs from different experimental areas were pooled in each season to compare the cost-benefit relationships between treatments and NTC. This analysis included the spray cost and the gross income of each treatment. Relative prices, as defined by the price index equation (equation 2), modified from Hoffmann (2006), were calculated for all treatments for each season separately and for T20 and CBS in a unified analysis of both seasons:

$$
\mathrm{PI}_{i}=\frac{\left(\mathrm{TGI}_{i}-\mathrm{TFAC}_{i}\right)}{\left(\mathrm{TGI}_{\mathrm{NTC}}-\mathrm{TFAC}_{\mathrm{NTC}}\right)}
$$

where $i$ was assigned a specific value for each treatment $(i=1$ for $\mathrm{T} 10, i=2$ for $\mathrm{T} 15, i=3$ for $\mathrm{T} 20$, and $i=4$ for $\mathrm{T} 25)$; $\mathrm{PI}_{i}$ is the price index (dimensionless) in treatment $i$; $\mathrm{TGI}_{i}$ is the total gross income for each treatment $i$;FAC $\mathrm{T}_{i}$ is the total fungicide application costs (spray cost $\times$ number of sprays) considering treatment $i$; TGI $_{\mathrm{NTC}}$ is the total gross income, considering the NTC treatment; and $\mathrm{TFAC}_{\mathrm{NTC}}$ is the total fungicide application costs in the NTC, which is null. The $\mathrm{PI}_{i}$ values were compared by Tukey test $(\alpha=0.05)$.

\section{Results}

Weather conditions and frequency of sprays. Weather conditions were conducive for PFD in all areas and seasons, although to different degrees. Daily conidial germination indexes ranged from 2 to $44 \%$ in season 1 and from 0 to $58 \%$ in season 2 (Figs. 2 and

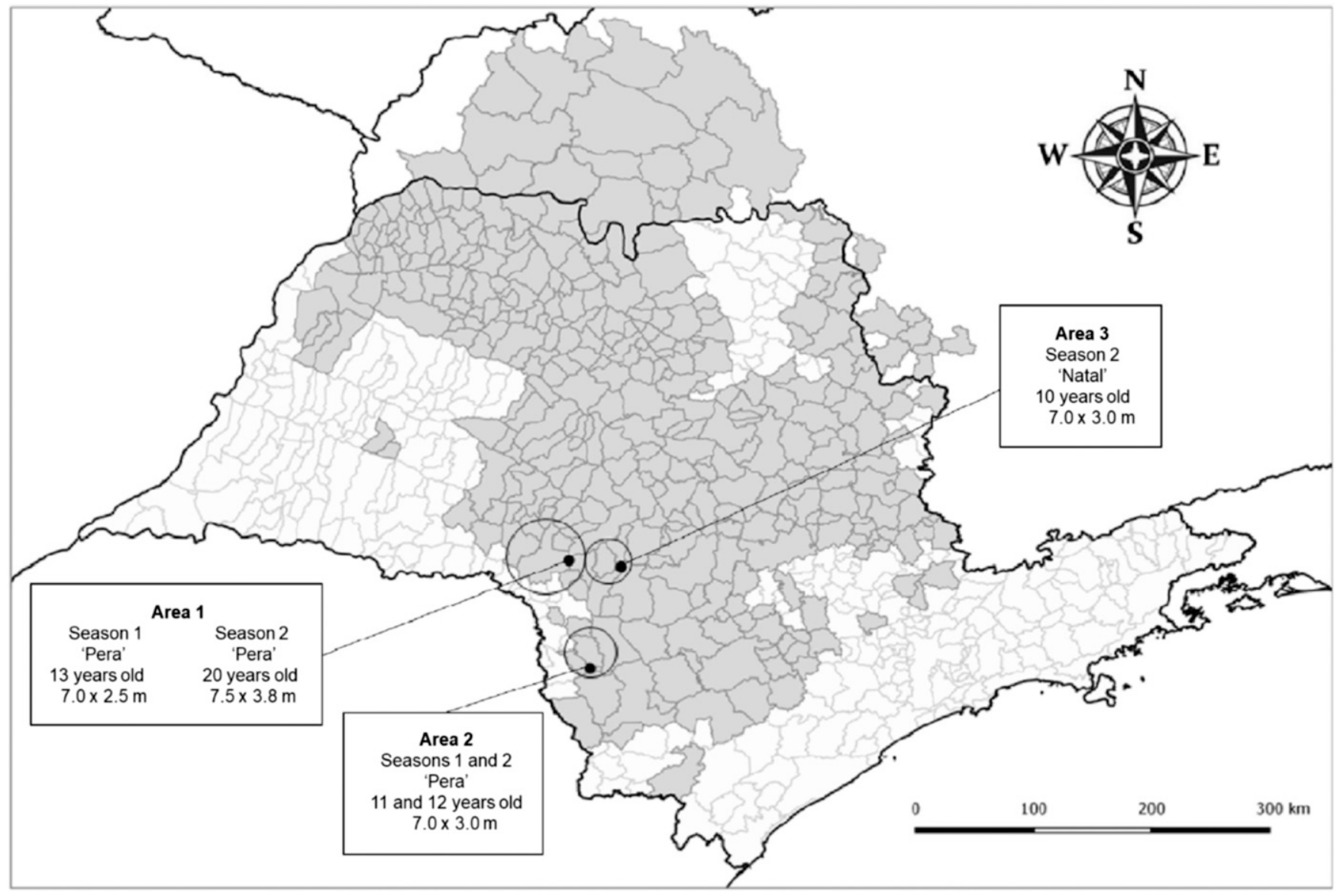

Fig. 1. Experimental areas (black dots) in the municipalities (circles) of Santa Cruz do Rio Pardo (area 1), Taquarituba (area 2), and laras (area 3), located in the southwestern region of citrus producing areas (darker gray) in São Paulo state, Brazil. Details on sweet orange cultivar, orchard age, and plant spacing of the three experimental areas for both seasons 1 and 2 are in the boxes. 
3). The flowering period was considerably shorter in season 1 (22 days in both areas 1 and 2) than in season 2 (45 days in area 1 and 58 days in areas 2 and 3) (Figs. 2 and 3). In the first season, three consecutive rainy days (rain $>0.2 \mathrm{~mm}$ ) were recorded toward the end of the flowering period in area 1 , which led to a wetness period of $40 \mathrm{~h}$ and a germination index of $34 \%$ (Fig. 2A). Although three sprays were made following the CBS treatment (on days 1, 8, and 14), only one application was indicated by T20 (at day 14) and T25 (at day 15) (Fig. 2A). Fungicide sprays were made three times in the CBS treatment in area 2 (3, 14, and 20 days after flowering). Treatments T20 and T25 were sprayed at day 14 , when the rain started, and wetness period reached $45 \mathrm{~h}$. Under these conditions, the germination index was $38 \%$. During the following 3 days, germination indexes were greater than $25 \%$ owing to long wetness periods associated with consecutive rainy days. However, the second spray was only performed at day 20, when the germination index reached $33 \%$, because no sprays were performed less than 7 days apart (Fig. 2B).
A higher frequency of rainy days was observed in season 2 for all areas compared with season 1 (Fig. 3). In area 1, 21 rain events were recorded during flowering. Rainfall was associated with long wetness periods and high germination indexes. The highest conidial germination index and the longest wetness period were, respectively, $51 \%$ and $58 \mathrm{~h}$, both predicted at day 35 . Five fungicide applications were performed following the CBS treatment, whereas thresholdbased treatments required fewer sprays, from two based on T15/ T20 to four based on T10 (Fig. 3A). The spray dates for each of the treatments in all the tests are indicated in Figure 3. In area 2, the weather station recorded 16 rainy days. More than $62 \mathrm{~mm}$ of rain occurred in a single day (Fig. 3B). The highest germination index and the longest wetness period were, respectively, $58 \%$ and $82 \mathrm{~h}$, at day 49. Six sprays were made following the CBS treatment, whereas five sprays were necessary for $\mathrm{T} 10$, and three sprays were required for T15 and T20 (Fig. 3B). In area 3, 12 rainy days occurred during the flowering period (Fig. 3C). The highest predicted germination

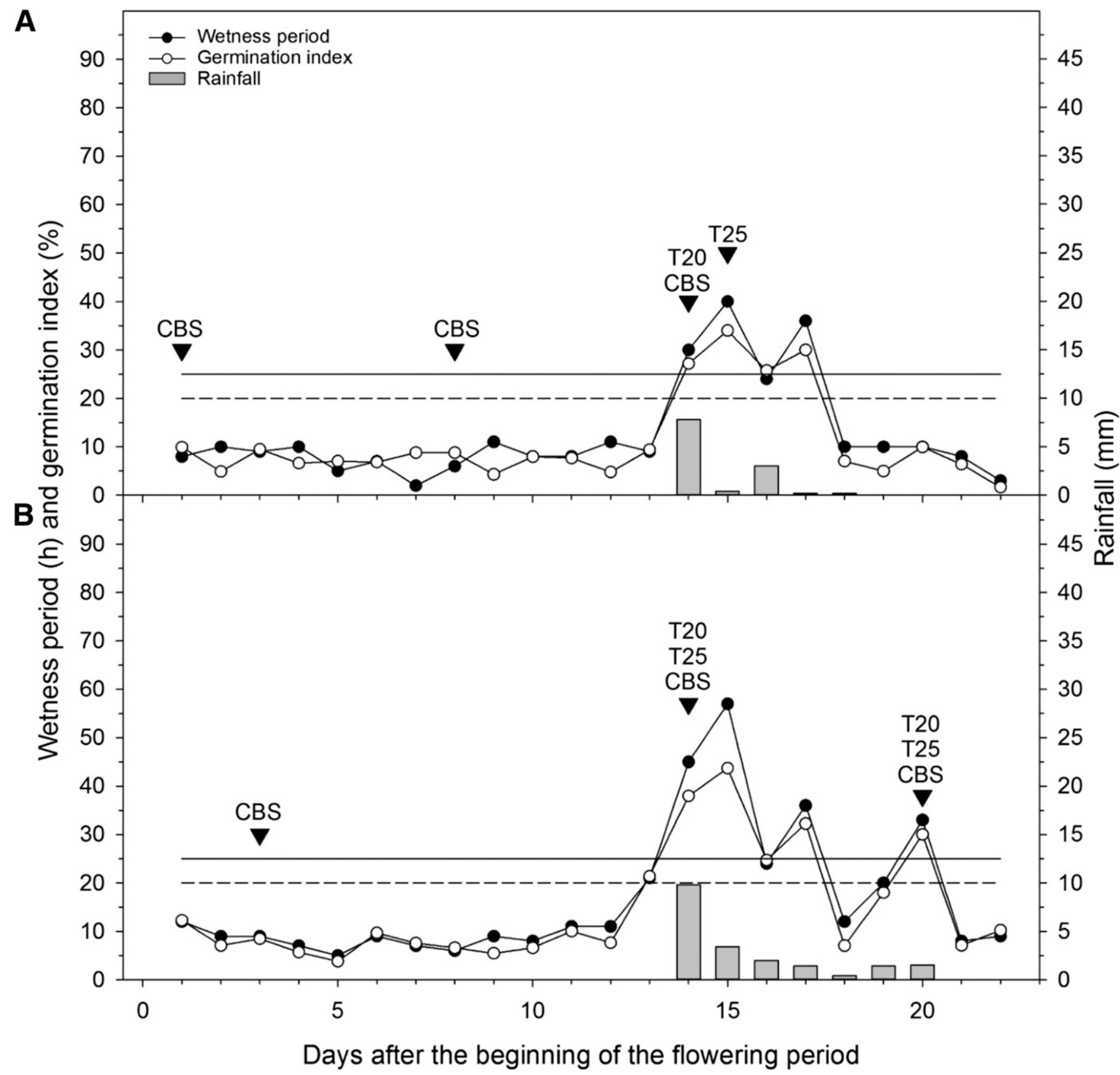

Fig. 2. Rainfall in millimeters (bars), calculated germination indexes, wetness period, and fungicide sprays (arrowheads) during the susceptible flowering period of area 1 (A) and area 2 (B) in season 1. Continuous line represents $25 \%$ conidial germination, and dashed line represents $20 \%$ conidial germination. Sprayed treatment acronyms are above each arrowhead. CBS corresponds to the calendar-based system; T20 and T25 correspond to the fungicide spray thresholds of 20 and $25 \%$ conidial germination, respectively. Flowering period initiated on August 12 in areas 1 and 2. 
index was $32 \%$ when the wetness period reached $36 \mathrm{~h}$. Eight sprays were made following the CBS treatment, whereas trees were sprayed five times based on T10 and twice for T15 and T20 (Fig. 3C). The first spray based on T20 was performed at day 34, in response to the $23 \%$ germination index recorded at day 33 . The trees from the T15 and T20 treatments were sprayed for the second time on days 44 and 47, respectively (Fig. 3C). The T20 fungicide application was delayed owing to operational problems.
Disease incidence and yield. In season 1, treatment effect on the proportion of symptomatic flowers was significant $(P<0.0001$ for both areas) and was significantly greater for the NTC than for other treatments (Fig. 4). The proportions of symptomatic flowers in the CBS treatment were 0.016 and 0.009 , respectively, in areas 1 and 2. PFD incidence on T20 was not significantly different from the CBS treatment in areas 1 and 2. The proportion of symptomatic flowers in areas 1 and 2 was, respectively, 0.025 and 0.002 . The

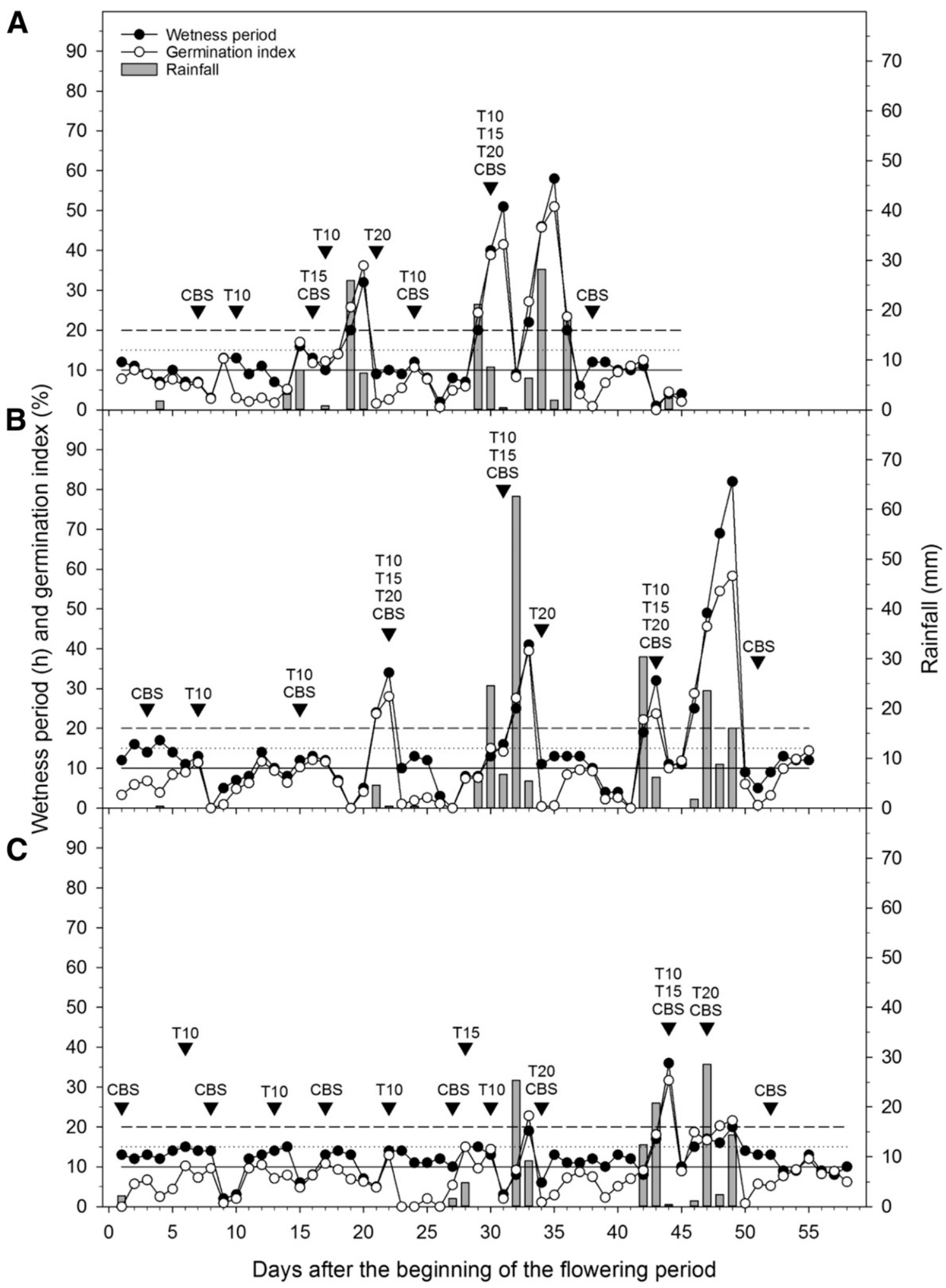

Fig. 3. Rainfall in millimeters (bars), calculated germination indexes, wetness period, and fungicide sprays (arrowheads) during the susceptible flowering period of area 1 (A), area 2 (B), and area 3 (C) in season 2. Dashed line represents $20 \%$ conidial germination, dotted line represents $15 \%$ conidial germination, and continuous line represents $10 \%$ conidial germination. Sprayed treatment acronyms are above each arrowhead. CBS corresponds to the calendar-based system; T10, T15, and T20 correspond to the fungicide spray thresholds of 10, 15, and 20\% conidial germination, respectively. Flowering period began on August 2 in area 1, whereas in areas 2 and 3 it began on July 20 . 
proportion of 0.057 diseased flowers observed with $\mathrm{T} 25$ in area 1 was significantly higher than PFD incidence in CBS. In area 2, T25 was less effective than CBS and T20 (Fig. 4), even though it resulted in low PFD incidence (0.019). The average number of persistent calyces per 10 branches in area 1 ranged from 14.43 to 30.06 , and treatment effect was not significant $(P=0.143)$. However, in area 2 , treatment effects on persistent calyces were significant $(P<$ 0.0001). Fungicide-sprayed treatments showed less than 1 persistent calyx per 10 branches, which was significantly lower than the 4.1 persistent calyces observed in NTC plots (Fig. 4). No difference in
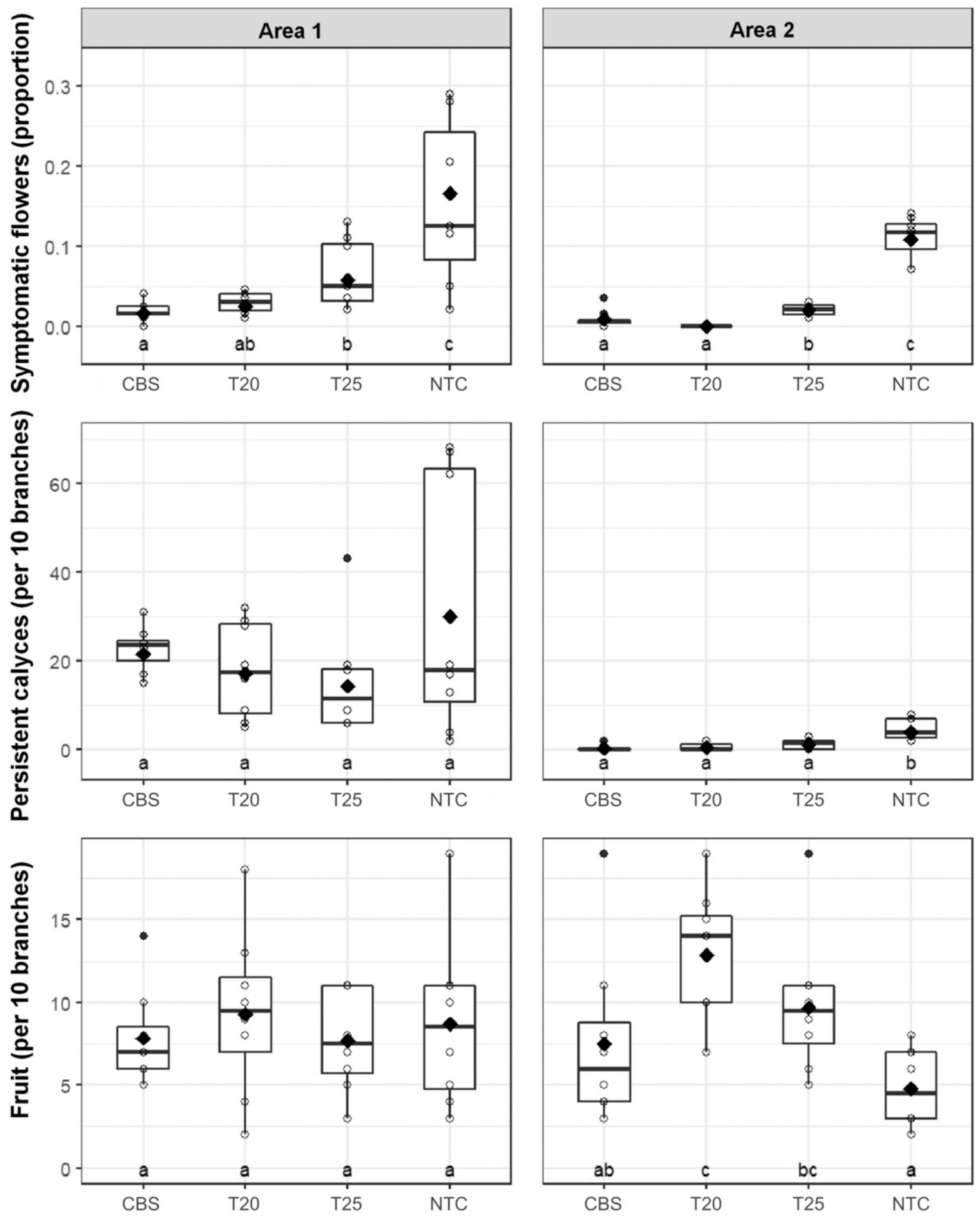

Fungicide spraying strategy

Fig. 4. Effect of different fungicide spray systems for control of postbloom fruit drop on the proportion of symptomatic flowers, the number of persistent calyces, and the number of fruit per 10 branches of sweet oranges in Santa Cruz do Rio Pardo (area 1) and Taquarituba (area 2), São Paulo state, Brazil, during season 1. CBS is the calendar-based system; T20 and T25 are the fungicide spray thresholds of 20 and $25 \%$ conidial germination, respectively; and NTC is the nontreated control. Boxplots showing model probability estimations $(-)$, mean value of each treatment $(\diamond)$, observations $(\circ)$, and outliers $(\bullet)$. Means designated by the same letter are not significantly different within the same season and area according to the Tukey test $(\alpha=0.05)$. Symptomatic flower incidence data followed quasibinomial and binomial distributions for areas 1 and 2, respectively. Quasi-Poisson and Poisson models better described the data on persistent calyces for areas 1 and 2, respectively. Poisson and quasi-Poisson models were used to describe fruit count data in areas 1 and 2 , respectively. 
the number of fruit per 10 branches was observed among treatments in area $1(P=0.85)$, and the average of fruit set ranged from 7.70 to 9.32 (Fig. 4). However, in area 2, the effect of the treatments on fruit set was significant $(P=0.0015)$. In area 2 , the highest yield was observed in T20 (12.88 fruit per 10 branches), which differed from CBS (7.48 fruit per 10 branches) and NTC (4.78 fruit per 10 branches) but was similar than T25 (9.69 fruit per 10 branches; Fig. 4).
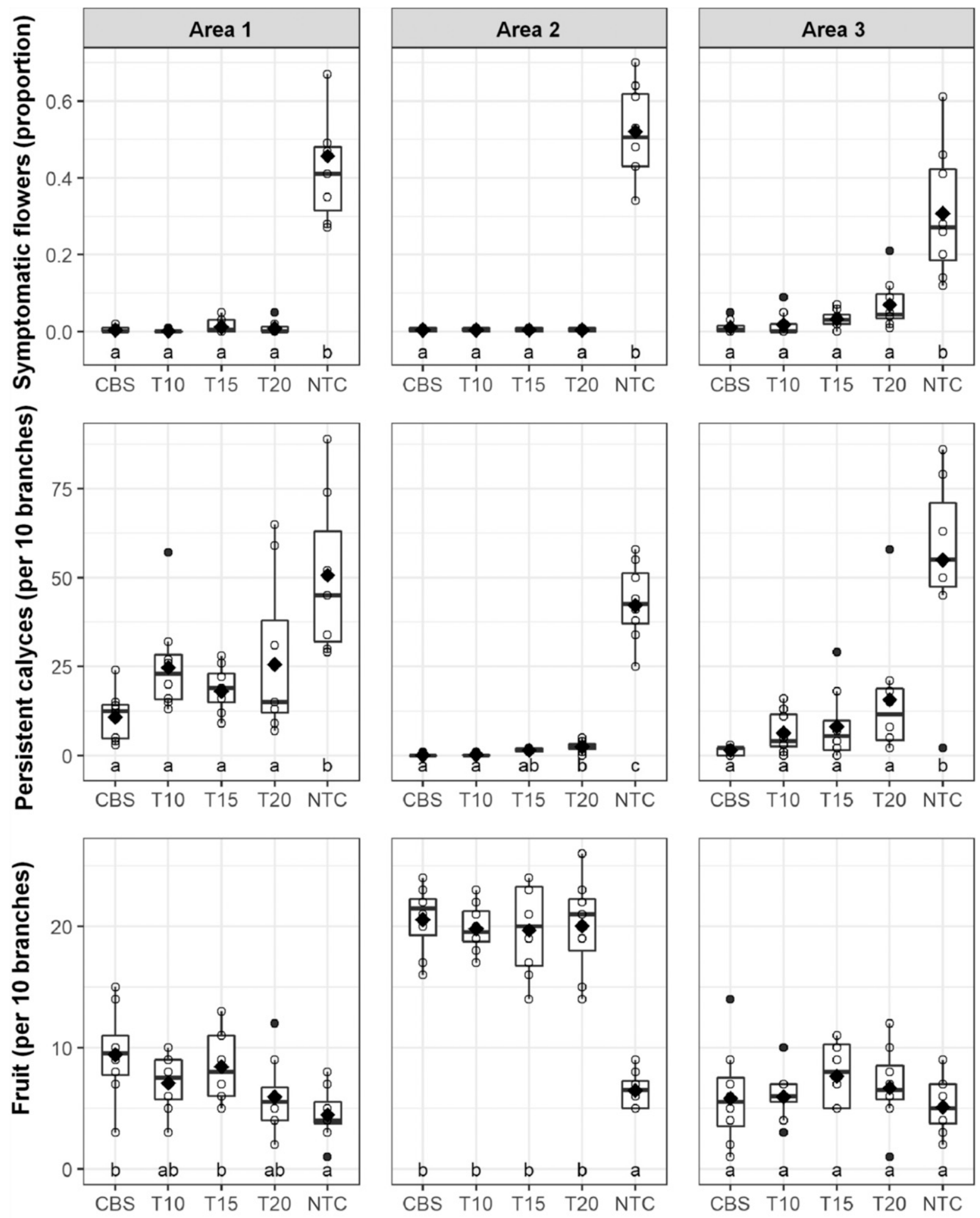

\section{Fungicide spraying strategy}

Fig. 5. Effect of different fungicide spray systems for control of postbloom fruit drop on the proportion of symptomatic flowers, the number of persistent calyces, and the number of fruit per 10 branches of sweet oranges in Santa Cruz do Rio Pardo (area 1), Taquarituba (area 2), and laras (area 3), São Paulo State, Brazil, during season 2 . CBS is the calendarbased system; T10, T15, and T20 are the fungicide spray thresholds at 10, 15, and 20\% conidial germination, respectively; and NTC is the nontreated control. Boxplots showing mean model probability estimations $(-)$, mean value of each treatment $(\bullet)$, observations $(\circ)$, and outliers $(\bullet)$. Means designated by the same letter are not significantly different within the same season and area according to the Tukey method $(\alpha=0.05)$. Symptomatic flower incidence data collected in areas 1 and 3 followed a quasibinomial distribution, whereas the binomial model better described the area 2 data. A quasi-Poisson model best described the persistent calyces data for areas 1 and 3 . Data collected in area 2 followed a Poisson distribution. For fruit count data, the Poisson and quasi-Poisson models were also used. Fruit count data obtained in areas 1 and 3 followed a quasi-Poisson distribution. Data collected in area 2 were best described by the Poisson model. 
In season 2, NTC plots always had the highest PFD incidence ranging from 31 to $52 \%$ symptomatic flowers (Fig. 5). Treatment effect on PFD incidence was significant $(P<0.0001)$ in all the experiments in season 2. No differences in PFD incidence were observed among CBS and the threshold treatments in any area. In these treatments, the average PFD incidence was close to zero in areas 1 and 2 and less than $10 \%$ in area 3 (Fig. 5). The treatment effect on the number of persistent calyces was significant $(P<0.0001)$ in season 2 . In NTC, it ranged from 42 to 55, which was higher than those observed in the treatments with fungicide sprays (Fig. 5). The number of persistent calyces per 10 branches in trees sprayed according to the thresholds or calendar ranged from 10.79 to 25.66 in area $1,0.12$ to 2.45 in area 2 , and 1.46 to 15.66 in area 3 . Number of fruit per 10 branches was significantly different among treatments in areas 1 and $2(P=0.0012$ and $P<0.0001$, respectively) but not in area 3 $(P=0.301)$. The highest yield, about 20 fruit per 10 branches, was observed in area 2 for treatments with fungicide sprays. In this area, the NTC showed only five fruit per 10 branches, which was significantly less than the number of fruit produced on treated trees. In areas 1 and 3, the average fruit set was lower than 10 fruit per 10 branches. Only in the area 1, NTC (five fruit per 10 branches) differed from CBS (10 fruit per 10 branches) and T15 (nine fruit per 10 branches; Fig. 5).

Economic analysis. Because the number of sprays was always greater for the CBS treatment than for the threshold-based spray treatments in all areas and seasons, the costs of sprays followed the

Table 1. Number of sprays, total spray cost, and estimated gross income in seasons 1 and 2 for areas 1,2 , and 3

\begin{tabular}{|c|c|c|c|}
\hline Treatment $\mathbf{t}^{\mathrm{x}}$ & $\begin{array}{c}\text { Number of } \\
\text { sprays }\end{array}$ & $\begin{array}{c}\text { Total spray cost } \\
\text { (US\$/ha)y }\end{array}$ & $\begin{array}{l}\text { Estimated gross } \\
\text { income (US\$/ha) }\end{array}$ \\
\hline \multicolumn{4}{|l|}{ Season 1} \\
\hline Area 1 & & & $P=0.844$ \\
\hline CBS & 3 & 101.21 & $6,427.47 \mathrm{NS}$ \\
\hline $\mathrm{T} 20$ & 1 & 33.74 & $7,608.39$ \\
\hline $\mathrm{T} 25$ & 1 & 33.74 & $6,402.15$ \\
\hline NTC & 0 & 0 & $7,178.19$ \\
\hline Area 2 & & & $P=0.037$ \\
\hline CBS & 3 & 75.01 & $5,211.27 \mathrm{bc}$ \\
\hline $\mathrm{T} 20$ & 2 & 50.01 & $8,638.73 \mathrm{a}$ \\
\hline $\mathrm{T} 25$ & 2 & 50.01 & $6,628.19 \mathrm{ab}$ \\
\hline NTC & 0 & 0 & $3,585.06 \mathrm{c}$ \\
\hline \multicolumn{4}{|l|}{ Season 2} \\
\hline Area 1 & & & $P=0.001$ \\
\hline CBS & 5 & 213.66 & $3,838.71 \mathrm{ab}$ \\
\hline $\mathrm{T} 10$ & 4 & 170.93 & $3,535.88 \mathrm{ab}$ \\
\hline T15 & 2 & 128.2 & $4,212.14 \mathrm{a}$ \\
\hline $\mathrm{T} 20$ & 2 & 128.2 & $3,060.27 \mathrm{ab}$ \\
\hline NTC & 0 & 0 & $2,497.34 \mathrm{~b}$ \\
\hline Area 2 & & & $P<0.0001$ \\
\hline CBS & 6 & 142.31 & $13,151.28 \mathrm{a}$ \\
\hline $\mathrm{T} 10$ & 5 & 118.6 & $12,712.24 \mathrm{a}$ \\
\hline $\mathrm{T} 15$ & 3 & 71.16 & $12,682.56 \mathrm{a}$ \\
\hline $\mathrm{T} 20$ & 3 & 71.16 & $13,151.28 \mathrm{a}$ \\
\hline NTC & 0 & 0 & $4,346.95 \mathrm{~b}$ \\
\hline Area 3 & & & $P=0.683$ \\
\hline CBS & 7 & 126.62 & $4,420.27 \mathrm{NS}$ \\
\hline $\mathrm{T} 10$ & 5 & 90.44 & $4,538.57$ \\
\hline $\mathrm{T} 15$ & 2 & 36.18 & $5,742.67$ \\
\hline $\mathrm{T} 20$ & 2 & 36.18 & $5,085.62$ \\
\hline NTC & 0 & 0 & $4,054.10$ \\
\hline
\end{tabular}

${ }^{\mathrm{x}} \mathrm{CBS}$ is the calendar-based system; T10, T15, T20, and T25 are the fungicide spray thresholds at $10,15,20$, and $25 \%$ conidial germination, respectively; and NTC is the nontreated control.

y Estimate based on costs of fungicide (US\$26.15/liter for season 1 and US $\$ 23.61 /$ liter for season 2), labor (US $\$ 2.22 / \mathrm{h}$ ), and machinery (US\$26.95/h).

${ }^{\mathrm{z}}$ The gross income refers to the value of a box of oranges of $40.8 \mathrm{~kg}$ for each year. NS $=$ not significant. Means followed by the same letter are not significantly different within the same season and area according to the Tukey test $(\alpha=0.05)$ same pattern (Table 1). In season 1, the CBS treatment in area 1 required three sprays and cost US $\$ 101 /$ ha, whereas the T20 and T25 treatments received only one spray at a cost of US\$34/ha. In area 2 , a smaller difference between the cost of the CBS treatment (US\$75/ha) and the threshold-based treatments (US\$50/ha) was observed. In season 2, the spray costs of the T15 and T20 treatments were always statistically equal and lower than spray costs of T10 (Table 1). Average price indexes in season 1 for T20, T25, and CBS were 1.82, 1.77, and 1.21, respectively. The price indexes of the different treatments in season 1 were greater for T20 than for T25 and CBS. There was no significant difference between T25 and CBS. Also, there were no significant differences in the estimated price indexes for treatments T10, T15, T20, and CBS in season 2, which were all in the range of 1.84 to 2.06 . The unified price index analysis of both seasons considering only T20 and CBS indicated that the increases in income were similar for T20 (1.84) and CBS (1.63). Overall, the predicted gross income was generally higher in threshold-based treatments and CBS than NTC only when fruit set was different. This was observed at significant levels in area 2, for which the gross incomes in NTC were US\$3,585.06 (season 1) and US\$4,346.95 (season 2), and in treatments that received fungicide sprays gross incomes were greater than US\$5,211.27 (season 1) and greater than US\$12,682.56 (season 2) (Table 1).

\section{Discussion}

In this study, the threshold-based system was more cost-efficient than the calendar-based sprays commonly used for PFD management by citrus growers for all areas and seasons. Based on the disease control, the number of fungicide sprays, the economic analysis, and the time it takes between a trigger and spray operations, T15 and T20 are recommended as thresholds to be used in a PFD-DSS. Wetness periods not related to rain events (i.e., caused by fog or dew) led to germination indexes of over $10 \%$ but never reached $15 \%$, although it does not exclude the possibility that this threshold could be reached in areas with prolonged fog duration. T10 was frequently reached and led to a similar number of fungicide sprays as the calendar-based program. Therefore, it could result in warnings when conditions are not highly conducive for PFD. T15 and T20 were similar in most cases, whenever rainfall occurred under mild to warm temperatures. For this reason, it was not possible to differentiate the control efficacy between T15 and T20. New trials under different weather conditions would be necessary to verify if the adoption of T15 is more appropriate when compared with $\mathrm{T} 20$ or vice-versa.

Regardless of the area and season, weather conditions were conducive to PFD. This is evident by the average incidences in the NTC that ranged from 11 to $52 \%$ diseased flowers. Under these conditions, threshold-based sprays reduced the number of and cost of sprays from 17 to $71 \%$ compared with the CBS treatment. Thresholds of 15,20 , and $25 \%$ conidial germination index all resulted in reductions in the costs and number of sprays (ranging from 33 to $71 \%$ ). Another DSS for PFD, PFD-FAD, when tested in Brazil, led to similar reductions in fungicide sprays ranging from approximately 30 to $70 \%$ when compared with the number of sprays performed by a grower (Peres et al. 2004). The reduction in the number of fungicide sprays from the adoption of our thresholds was within the same range as the one obtained with StAS, which reduced the number of fungicide sprays by about $50 \%$ on several seasons in Florida and in Ohio (Cordova et al. 2017, 2018). For mango anthracnose, a disease control decision system based on different threshold levels for Colletotrichum sp. infection also reduced the number of sprays from 40 to 80\% (Peak et al. 1986).

Despite the reduction on the number of sprays, the incidence of diseased flowers was similar in the threshold-based sprays and CBS, except when fungicide spray was delayed after the threshold alert. This occurred for T25 in area 1 and season 1 because the threshold was reached at night and the corresponding fungicide application could only be performed the following day. During season 2 in area 1 , T20 could only be sprayed 2 days after the alert, because it occurred on a Saturday. This could explain why the number of fruit in this treatment was equal to the NTC, even though it was also 
statistically equal to CBS-treated plots. However, in area 3 during season 2, the last fungicide spray for T20 could only be performed 2 days after the trigger, also owing to operational difficulties, although it did not result in differences in the proportion of symptomatic flowers. This could be related to the residual effect of the fungicide application performed on T20 at day 34. A similar issue has been reported by Bhatia et al. (2003), in which the authors found that some sprays targeting Alternaria brown spot were not always on the same day as the Alter-Rater DSS indicated. However, that did not affect disease control.

The treatments with fungicide sprays always reduced the symptoms on flowers compared with the NTC, but reductions in PFD incidence in sprayed plots did not lead to increased yield in three of the five experiments. This was also observed in experiments that evaluated PFD-FAD in Brazil (Peres et al. 2004) and in trials that evaluated a DSS for mango anthracnose control (Peak et al. 1986). Such observations may be owing to various causes: (i) as for several other diseases (Zadoks and Schein 1979), there is a level of PFD incidence below which no yield reduction occurs (Timmer and Zitko 1993); (ii) citrus trees produce a great number of flowers, but only 0.1 to $3 \%$ of them develop into fruit, depending on the cultivar and flowering intensity (Guardiola 1997); (iii) fruit set may vary with environmental conditions, such as dry soil and heat stress (Gene Albrigo and Galán Saúco 2004); and (iv) in the orchards, neighboring citrus trees under the same environmental conditions show great variation in yield, and it is not possible to accurately forecast the yield based on data from the previous season (Ye et al. 2008).

One of the problems related to DSS adoption is that information delivery is not timely enough to allow stakeholders to plan and expediently apply the recommended action (Rossi et al. 2014). As a result, disease control is hampered and might not be effective, especially in large citrus groves. Delayed sprays may also occur in other situations, including areas in which nighttime applications are not possible, during holidays or weekends when labor is not available, and during periods in which rainfall is continuous after the thresholds are reached. This is a common issue with DSS, and such problems are even more relevant to large-acreage farms, which are common to the Brazilian citrus industry. Because the models used in our investigation predict the probability of conidial germination, delayed fungicide application could be performed curatively once fungicide sprays were conducted after thresholds were reached. Results of threshold-based sprays, which were performed within $24 \mathrm{~h}$ after the alerts, demonstrated the effectiveness of the curative treatment of the mixture of trifloxystrobin + tebuconazole for PFD control. Similar results were observed for strawberry crown rot and anthracnose, also caused by Colletotrichum sp., in which the application of pyraclostrobin one day after inoculation of the pathogen effectively controlled the disease (MacKenzie et al. 2009; Turechek et al. 2006). Benomyl was also efficient in controlling citrus pathogenic C. acutatum when applied within $24 \mathrm{~h}$ after inoculation (Peres et al. 2002b).

Curative applications of fungicides when pathogen population density is high may represent a greater selection for resistant isolates (van den Berg et al. 2013). However, there is no evidence that the adoption of threshold-based systems facilitates the establishment of fungicide-resistant populations (van den Bosch et al. 2015). Timed sprays maximize the effective life of a fungicide, and there is not enough evidence to recommend refraining from curative sprays over preventive ones (van den Berg et al. 2013). In addition, we believe that the reduction in the number of sprays provided by predictive systems would outweigh the impact of several calendar-based preventive sprays in the selection pressure for fungicide resistance.

Nevertheless, it would be possible to apply preventive PFDcontrol strategies if forecast models could precisely predict the weather variables necessary for the calculation of PFD-risk indexes in the DSS. The use of an accurate forecast may improve acceptance of a DSS by growers, mainly on large farms, because they can plan their activities in advance. This kind of forecast is provided in other DSSs such as StAS for strawberry diseases (Pavan et al. 2011), Penn State Apple Orchard Consultant (PSAOC) system for apple diseases
(Magarey et al. 2002), and vite.net for grapevine diseases (Rossi et al. 2014).

Although the DSS requires that the growers have an automated weather station, the DSS, when available, is intended to be free of cost. If only spray costs are considered (i.e., disregarding income increases), the adoption of the T15 and T20 thresholds provided average savings of approximately US\$50/ha and US\$100/ha in seasons 1 and 2, respectively. Considering that in Brazil, a weather station costs approximately US $\$ 6,000.00$, these average savings obtained in seasons 1 and 2 would surpass equipment costs on farms larger than 120 and 60 ha, respectively.

There are several challenges to overcome to ensure that the results obtained in this work will be accepted and adopted by growers once they are incorporated in a PFD DSS. Technical, professional, economic, social, and psychological aspects are among the reasons for limited DSS acceptance (Shtienberg 2013). DSS usage is negatively influenced by the requirement for constant field evaluations, large property size, scarcity of economic incentives to replace traditional systems, inability to interact with other computer software used on the farm, lack of compatibility between DSS and decisions taken by the growers, and a requirement for direct grower-consultant interaction (Jørgensen et al. 2008). Typically, systems are used for as long as growers can obtain information from the platform that is new and relevant. When users learn new information and routinely incorporate it into agricultural decisions, the system falls into disuse (Gent et al. 2013). However, the sporadic occurrence of PFD and its high dependency on favorable weather within and among seasons implies a greater difficulty to predict epidemic dynamics. The more difficult it is to predict an epidemic, the more useful the system, because it provides risk assessments that cannot be readily estimated by farmers (Gent et al. 2013). We hope that our results contribute positively to the development of a new PFD DSS that will be widely adopted and that can provide a more sustainable and efficient strategy for PFD control for citrus growers in Brazil.

\section{Acknowledgments}

The authors are thankful to Citrosuco, Agroterenas and Castelfranco citrus groups for kindly allowing us to conduct the trials on their farms, to Luiz Antônio L. Ortiz, Silvia de A. Lourenço, Gleison O. Santos, William A. Ferreira, Marcelo Scapin, and Fabrício E. Lanza for technical assistance, and to Leandro G. Cordova for the valuable suggestions for this manuscript.

\section{Literature Cited}

Agostini, J. P., Gottwald, T. R., and Timmer, L. W. 1993. Temporal and spatial dynamics of postbloom fruit drop of citrus in Florida. Phytopathology 83: 485-490.

Agostini, J. P., and Timmer, L. W. 1994. Population dynamics and survival of strains of Colletotrichum gloeosporioides on citrus in Florida. Phytopathology 84:420-425.

Agostini, J. P., Timmer, L. W., and Mitchell, D. J. 1992. Morphological and pathological characteristics of strains of Colletotrichum gloeosporioides from citrus. Phytopathology 82:1377-1382

Agustí, M., Zaragoza, S., Bleiholder, H., Buhr, L., Hack, H., Klose, R., and Staub, R. 2000. The BBCH scale for describing phenological stages in citrus development. Pages. 445-446 in: Proc. IX Int. Soc. Citricult. Congr., Orlando, FL.

Bhatia, A., Roberts, P. D., and Timmer, L. W. 2003. Evaluation of the Alter-Rater model for timing of fungicide applications for control of Alternaria brown spot of citrus. Plant Dis. 87:1089-1093.

Brent, K. J., and Hollomon, D. W. 2007. Fungicide Resistance in Crop Pathogens: How Can It Be Managed?, 2nd Ed. FRAC Monograph 1. http://www.frac.info/ docs/default-source/publications/monographs/monograph-1.pdf. CropLife International, Brussels, Belgium.

Brown, A. E., Sreenivasaprasad, S., and Timmer, L. W. 1996. Molecular characterization of slow-growing orange and key lime anthracnose strains of Colletotrichum from citrus as C. acutatum. Phytopathology 86:523-527.

Cordova, L. G., Ellis, M. A., Wilson, L. L., and Madden, L. V. 2018. Evaluation of the Florida Strawberry Advisory System for control of Botrytis and anthracnose fruit rots in Ohio. Plant Health Prog. 19:182-187.

Cordova, L. G., Madden, L. V., Amiri, A., Schnabel, G., and Peres, N. A. 2017. Meta-analysis of a web-based disease forecast system for control of anthracnose and Botrytis fruit rots of strawberry in southeastern United States. Plant Dis. 101:1910-1917.

Damm, U., Cannon, P. F., Woundenberg, J. H. C., and Crous, P. W. 2012. The Colletotrichum acutatum species complex. Stud. Mycol. 73:37-113. 
de Goes, A., Garrido, R. B. O., Reis, R. F., Baldassari, R. B., and Soares, M. A. 2008. Evaluation of fungicide applications to sweet orange at different flowering stages for control of postbloom fruit drop caused by Colletotrichum acutatum. Crop Prot. 27:71-76.

Fagan, H. J. 1979. Postbloom fruit drop, a new disease of citrus associated with a form of Colletotrichum gloeosporioides. Ann. Appl. Biol. 91:13-20.

Fitzell, R. D., and Peak, C. M. 1984. The epidemiology of anthracnose disease of mango: Inoculum sources, spore production and dispersal. Ann. Appl. Biol. 104:53-59.

Forcelini, B. B., Seijo, T. E., Amiri, A., and Peres, N. A. 2016. Resistance in strawberry isolates of Colletotrichum acutatum from Florida to quinoneoutside inhibitor fungicides. Plant Dis. 100:2050-2056.

Frare, G. F., Couto, H. T. Z., Ciampi-Guilardi, M., and Amorim, L. 2016. The causal agent of citrus postbloom fruit drop, Colletotrichum acutatum, can survive on weeds.Austral. Plant Pathol. 45:339-346.

Fundecitrus. 2018. Tree inventory and orange crop forecast for São Paulo and West-Southwest Minas Gerais citrus belt. Retrieved 26 October 2018 from https://www.fundecitrus.com.br/pdf/pes_relatorios/Tree_Inventory_and_Orange_ Crop_Forecast_2018-2019.pdf

Gene Albrigo, L., and Galán Saúco, V. 2004. Flower bud induction, flowering and fruit-set of some tropical and subtropical fruit tree crops with special reference to citrus. Acta Hortic. 632:81-90.

Gent, D. H., Mahaffee, W. F., McRoberts, N., and Pfender, W. 2013. The use and role of predictive systems in disease management. Annu. Rev. Phytopathol. 51:267-289.

Gillespie, T. J., Srivastava, B., and Pitblado, R. E. 1993. Using operational weather data to schedule fungicide sprays on tomatoes in southern Ontario, Canada. J. Appl. Meteorol. 32:567-573.

Gonçalves, F. P., and Amorim, L. 2013. Temperatura e molhamento requeridos para a infecção de Colletotrichum acutatum e C. gloeosporioides em flores de laranjeira doce. $46^{\circ}$ Congresso Brasileiro de Fitopatologia - Ouro Preto. Trop. Plant Path. 38(Supplement):446.

Guardiola, J. L. 1997. Overview of flower bud induction, flowering and fruit set. Pages 5-21 in: Proceedings of Citrus Flowering and Fruit Short Course, IFAS. Citrus Research and Education Center, University of Florida, Gainesville, FL.

Hoffmann, R. 2006. Estatística para economistas, 4th Ed. Pioneira Thomson Learning, São Paulo, Brazil.

Huber, L., and Gillespie, T. J. 1992. Modeling leaf wetness in relation to plant disease epidemiology. Annu. Rev. Phytopathol. 30:553-577.

Hughes, G., and Madden, L. V. 1995. Some methods allowing for aggregated patterns of disease incidence in the analysis of data from designed experiments. Plant Pathol. 44:927-943.

Jørgensen, L. N., Noe, E., Nielsen, G. C., Jensen, J. E., Orum, J. E., and Pinnschmidt, H. O. 2008. Problems with disseminating information on disease control in wheat and barley to farmers. Eur. J. Plant Pathol. 121:303-312.

Lahey, K. A., Yuan, R., Burns, J. K., Ueng, P. P., Timmer, L. W., and Chung, K. R. 2004. Induction of phytohormones and differential gene expression in citrus flowers infected by the fungus Colletotrichum acutatum. Mol. Plant-Microbe Interact. 17:1394-1401

Lenth, R. V. 2016. Least-squares means: The R package lsmeans. J. Stat. Softw. 69:1-33

Li, W., Yuan, R., Burns, J. K., Timmer, L. W., and Chung, K.-R. 2003. Genes for hormone biosynthesis and regulation are highly expressed in citrus flowers infected with the fungus Colletotrichum acutatum, causal agent of postbloom fruit drop. J. Am. Soc. Hortic. Sci. 128:578-583.

Lima, W. G., Spósito, M. B., Amorim, L., Gonçalves, F. P., and Filho, P. A. M. 2011. Colletotrichum gloeosporioides, a new causal agent of citrus postbloom fruit drop. Eur. J. Plant Pathol. 131:157-165.

Lin, Y., Stover, E., Sonoda, R., and Rosskopf, E. 2001. Stigma and style necrosis is associated with postbloom fruit drop disease in citrus following artificial inoculation. HortScience 36:1138.

MacKenzie, S. J., Mertely, J. C., and Peres, N. A. 2009. Curative and protectant activity of fungicides for control of crown rot of strawberry caused by Colletotrichum gloeosporioides. Plant Dis. 93:815-820.

MacKenzie, S. J., Peres, N. A., and Timmer, L. W. 2010. Colonization of citrus leaves and secondary conidiation response to citrus flower extracts by nonpostbloom fruit drop strains of Colletotrichum acutatum. Trop. Plant Pathol. 35:333-342.

Madden, L. V., and Ellis, M. A. 1988. How to develop plant disease forecasters. Pages 191-206 in: Experimental Techniques in Plant Disease Epidemiology. J. Kranz and J. Rotem, eds. Springer-Verlag, Heidelberg, Germany.

Madden, L. V., Ellis, M. A., Lalancette, N., Hughes, G., and Wilson, L. L. 2000. Evaluation of a disease warning system for downy mildew of grapes. Plant Dis. 84:549-554.

Magarey, R. D., Travis, J. W., Russo, J. M., Seem, R. C., and Magarey, P. A. 2002. Decision support systems: Quenching the thirst. Plant Dis. 86:4-14.

Marques, J. P. R., Amorim, L., Spósito, M. B., and Appezzato-da-Glória, B. 2013. Histopathology of postbloom fruit drop caused by Colletotrichum acutatum in citrus flowers. Eur. J. Plant Pathol. 135:783-790.
McGovern, R. J., Seijo, T. E., Hendricks, K., and Roberts, P. D. 2012. New report of Colletotrichum gloeosporioides causing postbloom fruit drop on citrus in Bermuda. Can. J. Plant Pathol. 34:187-194.

Montone, V. O., Fraisse, C. W., Peres, N. A., Sentelhas, P. C., Gleason, M., Ellis, M., and Schnabel, G. 2016. Evaluation of leaf wetness duration models for operational use in strawberry disease-warning systems in four US states. Int J. Biometeorol. 60:1761-1774.

Pavan, W., Fraisse, C. W., and Peres, N. A. 2011. Development of a web-based disease forecast system for strawberries. Comput. Electron. Agric. 75:169-175.

Peak, C. M., Fitzell, R. D., Hannah, R. S., and Batten, D. J. 1986. Development of a microprocessor-based data recording system for predicting plant disease based on studies on mango anthracnose. Comput. Electron. Agric. 1:251-262.

Peres, N. A., and Dewdney, M. M. 2018. 2018-2019 Florida citrus production guide: Postbloom fruit drop. Retrieved 7 January 2018 from https://crec.ifas.ufl.edu/ extension/pest/PDF/Postbloom\%20Fruit\%20Drop.pdf. IFAS Extension - University of Florida, Gainesville, FL.

Peres, N. A., Timmer, L. W., Adaskaveg, J. E., and Correll, J. C. 2005. Lifestyles of Colletotrichum acutatum. Plant Dis. 89:784-796.

Peres, N. A. R., Kim, S., Beck, H. W., Souza, N. L., and Timmer, L. W. 2002a. A fungicide application decision (FAD) support system for postbloom fruit drop of citrus (PFD). Plant Health Prog. 3. doi: 10.1094/PHP-2002-0731-01-RV.

Peres, N. A. R., Souza, N. L., Furtado, E. L., and Timmer, L. W. 2004. Evaluation of systems for timing of fungicide sprays for control of postbloom fruit drop of citrus in Brazil. Plant Dis. 88:731-735.

Peres, N. A. R., Souza, N. L., Zitko, S. E., and Timmer, L. W. 2002b. Activity of benomyl for control of postbloom fruit drop of citrus caused by Colletotrichum acutatum. Plant Dis. 86:620-624.

Pertot, I., Caffi, T., Rossi, V., Mugnai, L., Hoffman, C., Grando, M. S., Gary, C. Lagond, D., Duso, C., Thiery, D., Mazzoni, V., and Anfora, G. 2017. A critical review of plant protection tools for reducing pesticide use on grapevine and new perspectives for the implementation of IPM in viticulture. Crop Prot. 97:70-84

R Core Team. 2018. R: A language and environment for statistical computing https://www.R-project.org/. R Foundation for Statistical Computing, Vienna, Austria.

Rossi, V., Salinari, F., Poni, S., Caffi, T., and Bettati, T. 2014. Addressing the implementation problem in agricultural decision support systems: The example of. vite.net. Comput. Electron. Agric. 100:88-99.

Shtienberg, D. 2013. Will decision-support systems be widely used for the management of plant diseases? Annu. Rev. Phytopathol. 51:1-16.

Silva-Junior, G. J., Spósito, M. B., Marin, D. R., and Amorim, L. 2014a. Efficacy and timing of application of fungicides for control of citrus postbloom fruit drop. Crop Prot. 59:51-56.

Silva-Junior, G. J., Spósito, M. B., Marin, D. R., Ribeiro-Junior, P. J., and Amorim, L. 2014b. Spatiotemporal characterization of citrus postbloom fruit drop in Brazil and its relationship to pathogen dispersal. Plant Pathol. 63:519-529.

Timmer, L. W., Agostini, J. P., Zitko, S. E., and Zulfiqar, M. 1994. Postbloom fruit drop, an increasingly prevalent disease of citrus in the Americas. Plant Dis. 78: 329-334.

Timmer, L. W., and Brown, G. E. 2000. Biology and control of anthracnose in citrus. Pages 300-316 in: Colletotrichum: Host Specificity, Pathology, and Host-Pathogen Interaction. D. Prusky, S. Freeman, and M. B. Dickman, eds. APS Press, St. Paul, MN.

Timmer, L. W., and Zitko, S. E. 1993. Relationships of environmental factors and inoculum levels to the incidence of postbloom fruit drop of citrus. Plant Dis. 77: 501-504.

Timmer, L. W., and Zitko, S. E. 1996. Evaluation of a model for prediction of postbloom fruit drop of citrus. Plant Dis. 80:380-383.

Turechek, W. W., Peres, N. A., and Werner, N. A. 2006. Pre- and post-infection activity of pyraclostrobinfor control of anthracnose fruit rot of strawberry caused by Colletotrichum acutatum. Plant Dis. 90:862-868.

van den Berg, F., van den Bosch, F., and Paveley, N. D. 2013. Optimal fungicide application timings for disease control are also an effective anti-resistance strategy: A case study for Zymoseptoria tritici (Mycosphaerella graminicola) on wheat. Phytopathology 103:1209-1219.

van den Bosch, F., Paveley, N., Fraaije, B., van den Berg, F., and Oliver, R. 2015 Pages 63-76 in: Fungicide Resistance in Plant Pathogens. H. Ishii and D. W. Hollomon, eds. Springer, Tokyo, Japan.

Ye, X., Sakai, K., Sasao, A., and Asada, S. 2008. Potential of airborne hyperspectral imagery to estimate fruit yield in citrus. Chemom. Intell. Lab. Syst. 90:132-144.

Zadoks, J. C., and Schein, R. D. 1979. Epidemiology and Plant Disease Management. Oxford University Press, New York, NY.

Zulfiqar, M., Brlansky, R. H., and Timmer, L. W. 1996. Infection of flower and vegetative tissues of citrus by Colletotrichum acutatum and C. gloeosporioides. Mycologia 88:121-128. 